\title{
Some aspects of the compatibility of mineral mining technologies
}

The Mining-Geology-Petroleum Engineering Bulletin UDC: 622.278 .273 .2

DOI: $10.17794 / \mathrm{rgn} .2018 .4 \cdot 7$

Original scientific paper

\author{
Roman Dychkovskyi ; Oleksandr Vladyko²; Dmytro Maltsev³, Edgar Cáceres Cabana ${ }^{4}$ \\ ${ }^{I}$ National Mining University, Faculty of Mining, Underground Mining Department, D. Yavornytskoho 21, UA-49000 Dnipro, Ukraine \\ ${ }^{2}$ National Mining University, Faculty of Mining, Underground Mining Department, D. Yavornytskoho 21, UA-49000 Dnipro, Ukraine \\ ${ }^{3}$ National Mining University, Faculty of Mining, Underground Mining Department, D. Yavornytskoho 21, UA-49000 Dnipro, Ukraine, - \\ ${ }^{4}$ National University of San Augustin, Institute of Renewable Energy Research and Energy Efficiency, San Agustin Street 107, PE-04000 \\ Arequipa, Peru
}

\begin{abstract}
Sometimes in mining, it is necessary to combine different extracting technologies within one enterprise. So, in this paper, the analysis of scientific and technical mining operations with combined technologies is carried out, and the search for structure and their operation in the mining enterprise is performed. The processes and technological parameters of mineral extraction by two fundamentally different technologies are investigated in detail. Due to the introduction of additional technologies, it is possible to involve sub-standard reserves in the production process, and an algorithm for determining the technological parameters is developed. This algorithm consists of criteria that make it possible to find compatibility in the work of one or more development technologies while maintaining an effective level of extraction. To do this, all processes at the enterprise are grouped: by degree of exploration, feasibility and economic efficiency. For each of them, certain coefficients were determined on the example of the operation of two specific combined technologies: the extraction of uranium ores and coal. For each group of criteria, certain coefficients are identified that allow assessing the feasibility of applying technology in their area. Their product is a general coefficient of compatibility, which shows the feasibility of introducing additional technology at the enterprise with the feasibility study. It defines the amount of funds invested in the development of an enterprise to achieve efficient mineral extraction with combined technologies within one enterprise. This point can be used to predict the grade variability of stockpiles from the origin source and the methodology allows characterizing the iron grades within stockpiles without any extra sampling.
\end{abstract}

\section{Keywords:}

combined mining technology, evaluation criterion, mineral extraction, economic efficiency

\section{Introduction}

Today, in Ukraine, a significant amount $(\sim 50 \%)$ of minerals is mined by the underground method, of which almost $90 \%$ is extracted from solid coal minerals and about $60 \%$ - ore minerals. However, over the last decade, about $60 \%$ coal mines in the country were closed because of the exhaustion of industrial reserves (Snihur et al., 2016; Petlovanyi et al., 2018). In order to increase profitability and reduce the number of closed extraction enterprises, it is possible to introduce additional development technology that will allow for the transformation of substandard reserves into industrial ones. In addition, the introduction of technology synthesis will increase: the completeness of mineral extraction, the efficiency of mining, increase the return on assets of the enterprise. However, the use of combined technologies complicates the management of the enterprise, forcing them to invent ways to

Corresponding author: Roman Dychkovskyi

dichre@yahoo.com manage processes that will be able to solve mining problems (Gorova et al., 2012; Smol et al., 2017; Tjiparuro et al., 2018) and national security because national security has ecological, economic, informational and even humanitarian components (Fatkhutdinov, \& Bazaluk, 2018). Accordingly, the effective use of additional technologies depends on a list of parameters such as exploration of the deposit, technological and technical parameters of extraction, expediency and the possibility of investment in the enterprise.

To determine the compatibility of the combined technologies, it is necessary to form the source data, design the algorithm for determining compatibility criteria and factors determining technology, which will determine the effectiveness of its implementation at the enterprise.

\section{Background}

Global and national scientific developments significantly expanded the limits of using standard technolo- 
gies, which increased the efficiency of mineral extraction in traditional methods through the introduction of modern equipment. Due to this, the standard quality reserves began to decrease sharply, resulting in the need to apply additional technologies for mineral development within the same production to improve the completeness of their extraction (Shemyakin, 2007; Zhao, 2010). At the same time, improving additional development technologies, researchers began to consider them as a more complex combined technology system (English, 2002). Additional technologies of development of minerals are often geotechnical methods of extraction, the development and implementation of which were and are still used by such scientists as: V. Zh. Arens, V.V. Rzhevsky and Ye.I. Shemyakin, Prof. D.P. Lobanov, Yu.D. Diadkin and I.I. Sharovar (Maltsev and Vladyko 2015; Khomenko et al., 2017) They proved the feasibility of using geotechnical methods of direct extraction in the rock mass and made preliminary calculations of the technological feasibility of their introduction into industrial production (Tabachenko et al., 2012).

\section{Main section}

\subsection{Brief description of the technology research}

The research is based on two examples of combined mining technology: the development of coal and uranium, and therefore there is a need to highlight them for future use as fundamental for the calculation and certain anchors in logic. The first technology is the technology of uranium extraction in Ukraine (Chernov, 1997). Uranium ore extraction companies widely use the roomand-pillar method with backfill (Singh \& Jayanthu, 2011).

Such mining methods provide technological development destroying rock mass with subsequent dumping through corresponding holes (cone raises) on the horizon, when they are separated and then output to the surface. Then the ore mass is transported to the concentration mill for further processing and enrichment; after that, the empty chamber is filled with hardening mixtures. In this technological process, transportation both to the surface and to the concentration mill is a substantial part of the cost of production, as well as the stowing operations, and additional processing (crushing and leaching) at the mill. Therefore, finding ways to reduce the cost of extracting uranium ore is an important issue for the company (Chen et al., 2018). A partial solution is to use geotechnological mining methods that enable a comprehensive reduction in transport and stowing operation costs. In the mining system, combined ore mining technology is considered as shown in Figure 1, where one part (on the right) presents an active mining method (room and pillar mining) and the other - additional (leaching).

The first technology is extraction using room and pillar mining (see $\mathbf{2}$ in Fig. 1). It is used in the development

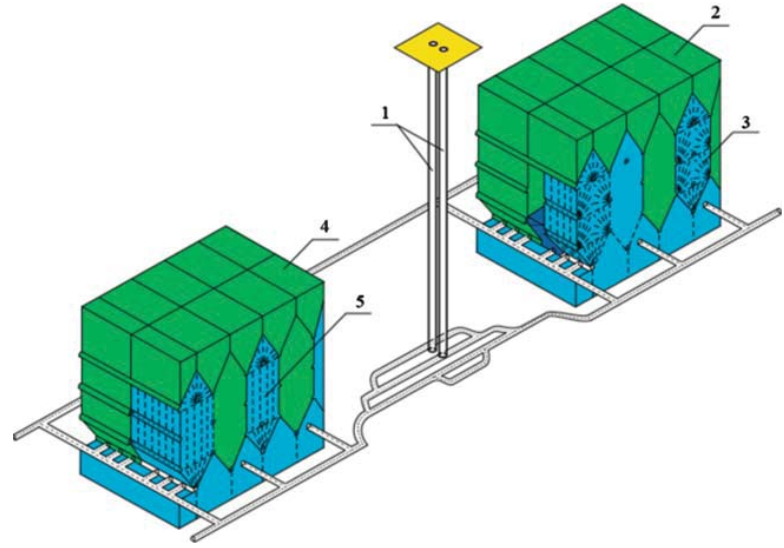

Figure 1: The combined technology of extracting uranium ore: $\mathbf{1}$ - the main and auxiliary shaft; $\mathbf{2}$ - extraction using room and pillar mining method; 3 - explosive wells fan; 4 - mining using the geotechnical method (leaching); 5 - wells for leaching

of ore deposits of different thickness and strength of ores and rocks. Stopping operations in this mining method are carried out in three stages: block undercutting, loose cutting and stopping operations. One of the important stages is destruction of rock mass through the drilling method and transportation to the surface. Stopping operations is organized in two or more steps. Broken ore is dumped using feeders or sloping the bottom of mine cars on the haulage horizon. Broken and crushed rock mass is dumped to the lower horizon, where it is transported to the shaft station, and then delivered to the surface for further transportation and processing.

The second technology is the extraction of minerals with the use of a geotechnical method of extraction, in this case, uranium is leached from rock mass using sulfuric acid (see 4 in Fig. 1). It presupposes obtaining minerals in liquid form. The leaching solution, fed to the mine, flows through the corresponding network to the productive horizon where the process of transferring the useful component into the solution takes place. Circulation of the solution is carried out by pump injection of the solution through the pipes from the upper part of the chamber to the bottom of the tank located on the lower haulage horizon. The cycle ends when the solution is saturated with useful substances and can no longer dissolve in it or dissolve significantly. After the productive solution reaches the desired concentration, it is removed from circulation and output to the surface for subsequent transportation and processing.

Another combined mining technology is used in the development of coal deposits. Implementation of this technology is schematically shown in Figure 2, which includes the extraction of coal by combine longwall (I) on the upper horizon, and well gasification on the lower one (II). Combine longwall mining is carried out using a mechanized complex which includes a shearer, mechanized support, and conveyer line, where the main ex- 


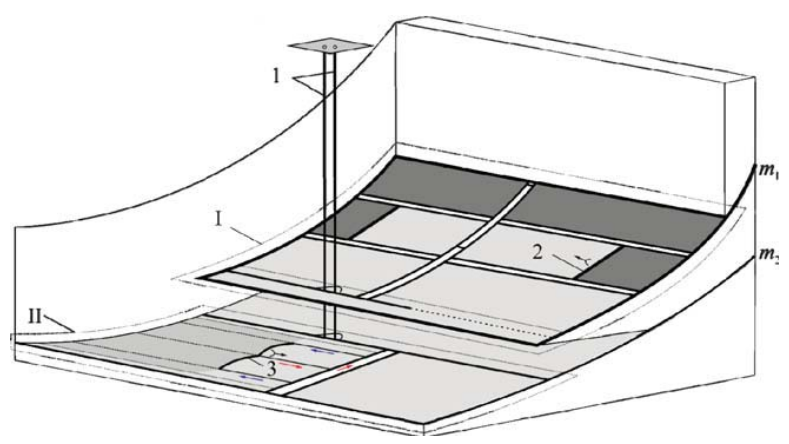

Figure 2: Combined technology for coal extraction:

I - mining using a combine method; II - extraction using well gasification; 1 - the main and auxiliary shaft; 2 - longwall; 3 - gas generator.

tracting operations are fulfilled by breaking the coal off the rock mass, and loading it on the face longwall conveyor using the shearer. As the stoping face moves, the goaf is filled with collapsed rocks of the roof or backfill material (Kuz'menko et al. 2013). A sufficient number of methods for improving the technological processes of coal mining reserves have been developed. The technological capability of this technology can also be determined by means of special software that has been tested for the extraction of the coal from thin seams (Pivnyak et al., 2013; Mahrous, 2018).

An additional technology for the development of coal is the well underground gasification of coal (WUGC), which consists of drilling inclined-horizontal wells on the coal seam, jointed together with the subsequent ignition of coal (Lavrov, 1957; Dychkovskyi, 2015; Xin et al., 2017; Falshtyns'kyy et al., 2013; Falshtynskyy et al., 2017; and other). This results in the formation of the fire face, which is controlled by a supply of steamoxygen air-blast. The resulting syngases are output to the surface, then they are decontaminated, and separated by components and only subsequently can be utilized (Pivnyak et al., 2017; Caceres \& Alca, 2016).

An important element of the gasification process is to ensure the stability of the gas generator channel (Khadse et al., 2006; Falshtyns'kyy et al., 2013). This paper presents a method for the formation of artificially created dual-layer melting of melted rocks, which provides the stability of the gas generator and prevents the penetration of the rocks into the working space of gasification (Dychkovskyi, 2015).

The deterrent factor for underground coal gasification is the replacement of the coal by the wall rocks in zones of various geological disturbances. In this situation, we can see the decay of thermochemical processes occurring in the coal and the need for re-ignition of the reactor in a geoprocessed zone. Analytical calculations and conducted research on the test installation prove the possibility of continuous overcoming of such problem zones and sufficiently complete extraction of coal by the gasifying method (Lozynskyi et al., 2016; Lozynskyi et al.,
2015; Dychkovskyi et al., 2018; Falshtynskyy et al., 2012). One of the ways to increase the productivity of a gas generator is the simultaneously multi-level preparation of coal horizons with the output of energy gases per one well (Saik et al., 2016).

The mining enterprise is functioning as a separate system, consisting of separate elements and connections between them, and is united by one goal. This goal is the sustainable extraction of minerals. To identify the interrelation of the combined technologies at the enterprise, it is necessary to analyse the main component of the system (company). We make segmentation according to the principle of compatibility of the enterprise activities, and, based on this, we split the mineral extraction process into three main parts. The first part refers to the quality and quantity of mineral extraction (deposit exploration coefficient), the second shows the level of technological development at the enterprise (technological complexity coefficient and the level of development of extraction technology), the third part deals with the economic efficiency of production (economic efficiency coefficient).

\subsection{Mutual influence of technologies}

In the interaction of two or more technologies, many variants of overlapping parameters (conflict areas) of their compatibility may occur. Let $T_{1}$ be the main technology and $T_{i}$ - an infinite number of other additional extraction technologies. Figure 3 shows a borderline case where the technologies interfere with each other maximally ( $100 \%$ conflict possibility), which prevents the simultaneous mining of each technology.

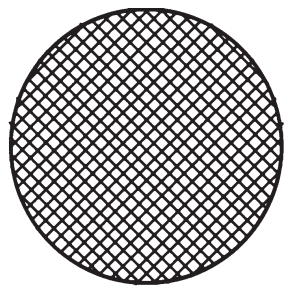

Figure 3: Borderline case of technologies overlapping with the highest complication of functioning

The extremely unfavourable borderline case of simultaneous involvement of technologies, indicated in Figure 3, is extremely rare, that's why the following case of overlapping technologies is the most common. In this case, with a certain percentage of probability, technologies partially hinder each other's work (see Figure 4)

And the last case, also a borderline one, similarly to the first variant (see Figure 3), is the ideal variant for simultaneous operation of the technologies (see Figure 5), where the technologies do not affect one another with independent operations, and therefore maximize performance. 


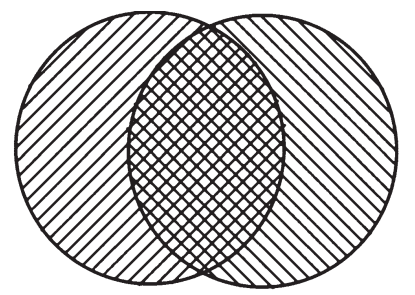

Figure 4: The overlapped area (possible trouble) of the simultaneous operation of the active and additional technologies


Figure 5: Borderline and the most favourable (independent) case of functioning of various technologies at the same enterprise

The technologies' interaction characteristics are present in mining enterprises, and they require a precise algorithm for determining the compatibility of technologies for efficient mining.

\subsection{Algorithm for determining technology compatibility}

The search for reserve extraction technology compatibility within a mining company is based on a combination of existing and additional technologies. In order to do this, we develop the algorithm of their possible combination (see Figure 6).

Below we give the calculation method for the coefficients in the algorithm.

\subsection{Principles of the incoming data formation and the deposit exploration coefficient}

One of the tasks of this paper is to increase the productivity of minerals by combining extraction technologies. We recommend calculating the compatibility of technologies in the process of extraction using the technology compatibility coefficient. To do this, it is necessary to select the source data for calculation.

The first type of source data includes mining and geological conditions of occurrence, which consist of graphic sections, tabular and textual data. These include:

- graphical representation of a mine field;

- network of geological faults and geological sections;

- thickness of coal seams and surrounding rock layers (strength, water content, the presence of inclusions, etc.);
- tabular characteristics of mineral deposits (thickness, dip angle, strength, fracture, etc.).

The second type includes data that characterizes the technological processes of the extraction of minerals at the enterprise. These include: information about technology extraction of reserves which contain the type and components of stoping and mining equipment; mine field opening layout; deposit preparation methods; mining method and direction of reserves extraction.

The third type of data includes economic indicators, that reflect the economic situation and are stored in the technical and economic departments of the enterprise. These include:

- prime cost of mining (technical and economic indicators of extraction);

- data about profit and loss of the enterprise;

- performance of equipment and workers;

- market prices for minerals.

In addition, there are external influences on the work of the company: the laws of the country governing the relations in this area, the state of technical and economic development of the country, etc.

To specify the field of input data, the coefficient of lithological difference is proposed on the example of two fundamentally different combined technologies (see Table 1).

The coefficient of lithological difference influencing the deposit extraction technology is determined with the following formula (1):

$$
K_{p 1}=\frac{k_{r . s .}+k_{r . t .}+k_{f . s .}+k_{f . t .}+k_{w p . s .}+k_{w p . t .}+k_{w . m .}+k_{p . m .}}{z_{i}}
$$

where: $\mathrm{z}_{i}$ is the number of studied parameters.

To assess the completeness of the field exploration, two main approaches are used: deterministic and probabilistic. Deterministic methods involve the analysis of cores from wells drilled in different parts of the mineral deposits, and their subsequent study using instrumental observations. As a result, data on mineral resources in general are accumulated. Probabilistic methods, in turn, use data from the deterministic method with the use of statistical analysis and/or mathematical algorithms, which allows for the obtainment of the probable occurrence (location) of useful minerals in those parts the field where the deterministic approach has not been applied. On the basis of this, we can formulate the calculation of the value of the complete coefficient of deposit exploration using formula (2):

$$
K_{p 2}=\frac{k_{m}+k_{a} \frac{1}{y} k_{z}+k_{n}+k_{p p}+k \ldots+k}{z_{i}},
$$

Where:

$k_{m}$ is the coefficient of the deposit thickness, which depends on mineral thickness and fluctuations within the research area, it is taken into account in coal and ore extraction. 


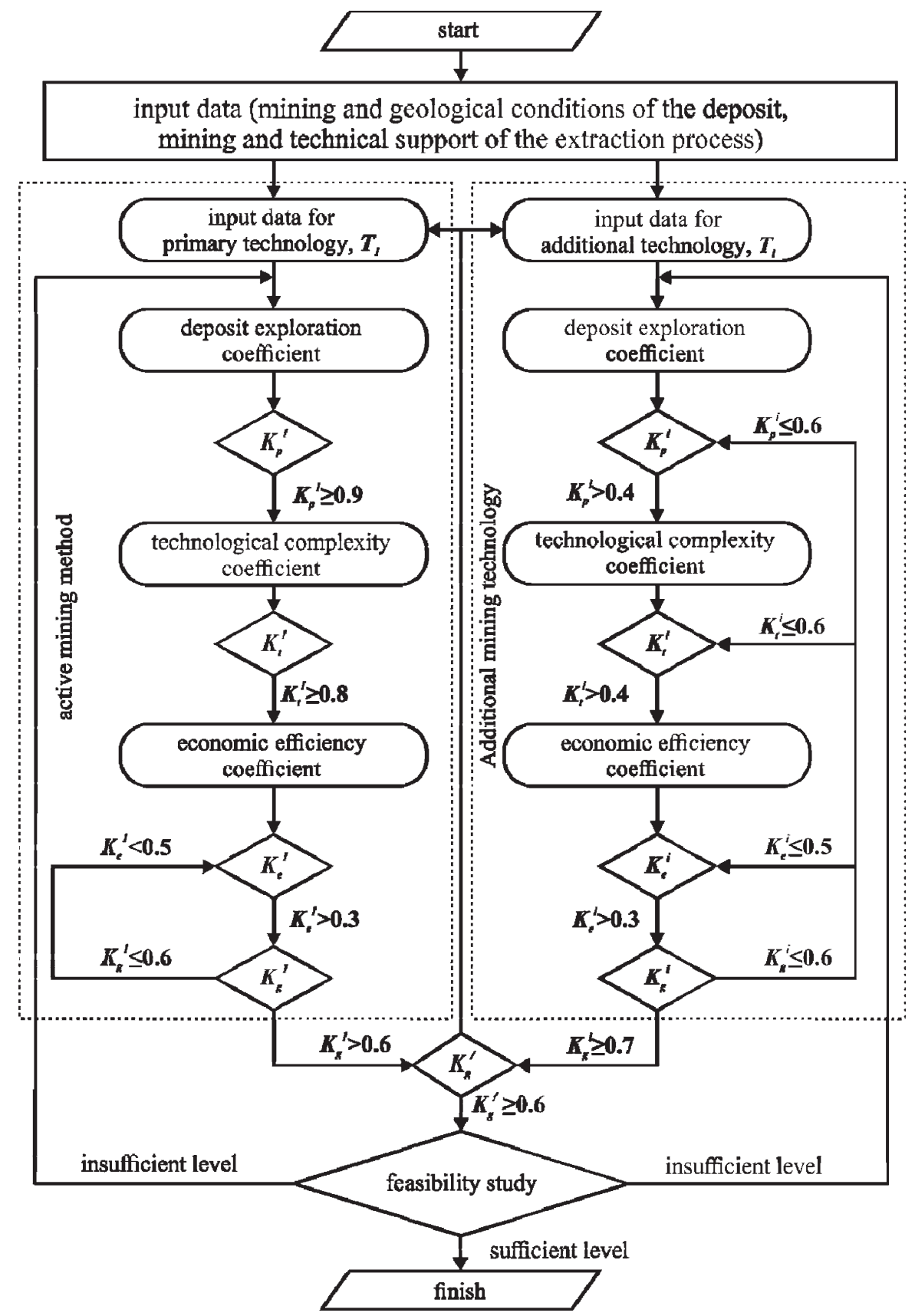

Figure 6: Algorithm of determining technologies compatibility expediency

In the case of combined technology of coal extraction with the seam thickness of $0.7 \mathrm{~m}$ to $2.0 \mathrm{~m}$, the coefficient is $k_{m}=1.0$ at $m=0.25-0.7 \mathrm{~m}$, and $k_{m}=0.9$, at $m=2.0$ $-5.0 \mathrm{~m} k_{m}=0.8$; at combined ore development with the deposit thickness from 3.0 to $10.0 \mathrm{~m}$, respectively, the value of the coefficient is $k_{m}=1$ at $m=0.5-3.0 \mathrm{~m}$, and $k_{m}=0.9$, at $m=10.0-15.0 \mathrm{~m} k_{m}=0.8$;

$k_{c}$ is the coefficient of structure and texture of the seam, the structure is characterized by the form, size and method of the combination of separate mineral grains or their fragments in spatially separated mineral aggre- gates; the texture is determined by the spatial arrangement of mineral aggregates that differ in composition, shape, size and structure, $k_{c}=0.80-0.95$;

$k_{z}$ is the coefficient taking into account the content of impurities in the deposit (for coal development it is ash content, for ore development it is calculated from the math expression $1-\alpha$, where $\alpha$ is the ore metal content), for coal and ore extraction $k_{z}=1$, for well gasification of coal $k \rightarrow 0$, if the ash content tends to 0 and when ore leaching $k_{z} \rightarrow 0$ at $\alpha \rightarrow 0$, i.e., it varies directly proportional; 
Table 1: Calculation of the influence of the lithological difference on the combined extraction technologies

\begin{tabular}{|c|c|c|c|c|}
\hline \multirow{3}{*}{ Indicator } & \multicolumn{4}{|c|}{$\begin{array}{l}\text { Combined technology of coal extraction (first line) } \\
\text { The combined technology of uranium ore extraction (second line) }\end{array}$} \\
\hline & \multicolumn{2}{|c|}{$\begin{array}{l}\text { Traditional shearer mining technology } \\
\text { Traditional room and pillar mining }\end{array}$} & \multicolumn{2}{|c|}{$\begin{array}{l}\text { Underground well gasification } \\
\text { Borehole underground leaching }\end{array}$} \\
\hline & bottom hanging side & roof bottom side & bottom hanging side & roof bottom side \\
\hline $\begin{array}{l}\text { Rock stability, } \\
k_{r . s} \text { and } k_{r . t .}\end{array}$ & \multicolumn{2}{|c|}{$\begin{array}{l}\text { Determined by the stability of rocks, the more } \\
\text { stable the rock type, the more directly proportional } \\
\text { the values are } k_{r . s}=0.5 \div 1 ; k_{r . t .} 0.5 \div 1\end{array}$} & \multicolumn{2}{|c|}{$\begin{array}{l}\text { There is no significant influence } k_{r . s}=0.9 \div 1 \text {; } \\
k_{r . t .}=0.8 \div 1\end{array}$} \\
\hline $\begin{array}{l}\text { Filtration of } \\
\text { rocks, } k_{f . s .} \text { and } k_{f . t .}\end{array}$ & \multicolumn{2}{|c|}{$\begin{array}{l}\text { There is no significant influence of filtering, values } \\
k_{f . s} \text { and } k_{f . t .} \text { equal a unit. }\end{array}$} & \multicolumn{2}{|c|}{$\begin{array}{l}\text { Determined by the rocks filtration, the greater the } \\
\text { filtration, the greater coefficient values, } k_{f . t}=0.5 \div 1.0 \text {, } \\
k_{f . t}=0.5 \div 1.0\end{array}$} \\
\hline \multirow[t]{2}{*}{$\begin{array}{l}\text { Inflow of water, } \\
k_{\text {wp.s. }} \text { and } k_{\text {wp.t. }}\end{array}$} & \multicolumn{2}{|c|}{$\begin{array}{l}\text { Determined by inflow of water, } k_{w p . s .}=0.5 \div 1 \text {; } \\
k_{w p . t}=0.5 \div 1 . \text { The greater the water flow, the less } \\
\text { directly proportional the values of the coefficients } \\
k_{w p . s .} \text { and } k_{\text {wp.t. }} \text { are. }\end{array}$} & \multirow{2}{*}{\multicolumn{2}{|c|}{$\begin{array}{l}\text { Determined by inflow of water, } \\
k_{w p . s}=0.7 \div 1.0, k_{w p . t .}=0.7 \div 1.0 . \text { The greater the water } \\
\text { flow, the less directly proportional the values of the } \\
\text { coefficients } k_{\text {wp.s. }} \text { and } k_{\text {wp.t. }} \text { are. }\end{array}$}} \\
\hline & Practically does not c & $k_{w p . s .}=1.0$ and $k_{w p . t}=1.0$ & & \\
\hline \multirow{2}{*}{$\begin{array}{l}\text { Water content } \\
\text { of deposit, } k_{w \cdot m} \text {. }\end{array}$} & \multicolumn{4}{|c|}{$\begin{array}{l}\text { Determined by the water content of deposit, and varies from } 0.4 \text { to } 1.0 \text {. The greater the water content } \\
\text { in } 1 \mathrm{~m}^{3} \text { of minerals, the less the value of } k \text { is. }\end{array}$} \\
\hline & \multicolumn{4}{|c|}{$\begin{array}{l}\text { Determined by the water content of deposit, and varies from } 0.8 \text { to } 1.0 \text {. The greater the water content } \\
\text { in } 1 \mathrm{~m}^{3} \text { of minerals, the less the value of } k_{w, m} \text { is. }\end{array}$} \\
\hline $\begin{array}{l}\text { Permeability } \\
\text { of deposit, } k_{p . m .}\end{array}$ & \multicolumn{2}{|c|}{$\begin{array}{l}\text { Determined by the permeability of deposit, and } \\
\text { varies from } 0.8 \text { to } 1.0 \text {. The greater the permeability } \\
\text { of minerals, the greater the value of } k_{n m} \text { is. }\end{array}$} & \multicolumn{2}{|c|}{$\begin{array}{l}\text { Determined by the permeability of deposit, and } \\
\text { varies from } 0.6 \text { to } 1.0 \text {. The greater the permeability } \\
\text { of minerals, the greater the value of } k_{p, m} \text { is. }\end{array}$} \\
\hline
\end{tabular}

$k_{n}$ is coefficient of development depth $\left(0 \mathrm{~m}<k_{n}=\right.$ $1.0<299 \mathrm{~m}$ and $300 \mathrm{~m}<k_{n}=0.8<500 \mathrm{~m}$ and deeper);

$k_{p p}$ is coefficient of geological faults availability from 1.0 to 0.5 depending on degree of geological faults (without geological faults $k_{p p}=1.0$, maximum permissible geological faults $\left.k_{p p}=0.5\right)$;

$z_{i}$ is the number of parameters taken into account.

As a result we calculate the exploration criterion with the value from 0.5 to 1.0 , which needs to be evaluated in a certain way for subsequent calculations with using the following formula (3):

$$
K_{p}=\frac{K_{p 1}+K_{p 2}}{2} .
$$

All possible results of this coefficient are summarized in Table 2.

\subsection{Technological parameters of extraction, and technological complexity coefficient}

Technological parameters of extraction depend on:

- physical and mechanical characteristics of minerals;

- degree of mineral extraction;

- location of workings in space and their formation in time;

- transportation methods and means in the technologies involved;

- technological schemes and technologies used;

- stoping works density.
Table 2: Value and specific weight of the deposit exploration coefficient

\begin{tabular}{|l|l|}
\hline Coefficient & Description of the coefficient value \\
\hline$K_{p}>0.9$ & $\begin{array}{l}\text { A full complex of physico-mechanical and } \\
\text { physico-chemical research has been carried } \\
\text { out. Mineral reserves are calculated with the } \\
\text { probability of up to 100\%. }\end{array}$ \\
\hline $0.6<K_{p}<0.9$ & $\begin{array}{l}\text { Deposit exploration might reach } 60 \% . \\
\text { The whole complex of physical-mechanical } \\
\text { and physical-chemical researches is not } \\
\text { carried out. Mineral reserves are calculated } \\
\text { with the probability of 50 - 80\%. }\end{array}$ \\
\hline $0.4<K_{p}<0.6$ & $\begin{array}{l}\text { Deposit exploration is in the range } \\
\text { of } 20-60 \% \text {. Mineral reserves are calculated } \\
\text { with the probability of up to 50\%. }\end{array}$ \\
\hline
\end{tabular}

Given the large number of parameters, it is necessary to consider the order of research of various mining methods at the same mining company:

- mining enterprise reserves which are suitable for the extraction by two technologies are researched, taking into account the technological breakthrough;

- the technological parameters of the additional technology for the given conditions are determined;

- compatibility check for active and additional technologies;

- the feasibility study of additional technology is conducted.

In order to substantiate the possibility of mining using combined technologies, it is necessary to determine their 
parameters and conduct compatibility research of technology recommended for using (synthesis) (Maltsev and Vladyko, 2015a; Vladyko, 2013).

List of technological factors that influence the estimation of combined extraction of minerals at the same deposit is as follows:

- adequate level of labour safety during extraction;

- provision of transportation of minerals, people, goods, etc.;

- use of various equipment for individual stages of the process, and its maintenance;

- methods and means for rock pressure control at working/stoping area.

Technological complexity coefficient of the deposit development is determined from the following formula, which takes into account the technological criteria for mineral extraction. It allows to compare the parameters of the extraction technologies by using formula (4):

$$
K_{T}=\frac{k_{p}+k_{w v .}+k_{s f}+k_{o}+k_{c t}+k_{m e}}{z_{i}},
$$

Where:

$k_{p}$ is the coefficient taking into account the method of preparation;

$k_{\text {opm }}$ is the coefficient that takes into account the order of the minerals mining;

$k_{w v}$ is the coefficient taking into account the ventilation method;

$k_{s f}$ is a technology safety factor that, when applied to one technology, reaches 0.9 ;

$k_{c t}$ is transport system complexity coefficient, which varies from 0.6 to 0.9 ;

$k_{m e}$ is the operation reliability coefficient of the mining equipment, which varies from 0.65 to 0.80 ;

$k_{o}$ is the efficiency coefficient of organizational decision-making, which varies from 0.5 to 1.0 .

The calculations result in the productivity criterion with the value of $K_{T}$ in the range of $0.4-1.0$, which presupposes the following gradation (see Table 3 ).

\subsection{Economic efficiency coefficient}

The economic efficiency coefficient allows for an estimate of combined technologies and provides quantitative and qualitative estimations of financial risks connected with exploration, estimation, and development of deposits. The method that allows the evaluation and comparison of different variants of combined technologies on this basis is proposed.

An important aspect of determining the effectiveness of combined development methods is the creation of tailor-made models or the use of existing analytical mechanisms for the economic evaluation of efficiency at all stages of mining operations: from commissioning the necessary equipment in operation, stoping and other operations, to taking them out of service.
Table 3: Value of the technological complexity coefficient

\begin{tabular}{|l|l|}
\hline Coefficient & Description of the coefficient value \\
\hline$K_{T}>0.9$ & $\begin{array}{l}\text { The highest level of implementation } \\
\text { of mineral extraction technologies and optimal } \\
\text { conditions for the use of mining equipment }\end{array}$ \\
\hline $0.6<K_{T}<0.9$ & $\begin{array}{l}\text { With the introduction of the mineral extraction } \\
\text { technology there occurs an imbalance of } \\
\text { mining equipment operation which leads } \\
\text { to a decrease in the coefficient value }\end{array}$ \\
\hline $0.4<K_{T}<0.6$ & $\begin{array}{l}\text { The sufficient minimum level of technologies } \\
\text { implementation, which allows for the } \\
\text { extraction of minerals }\end{array}$ \\
\hline
\end{tabular}

This criterion includes the following indicators:

- the cost of minerals, which depends on the situation at the raw material market, the location of the deposit and the investment climate in the industry;

- availability of industrial processing of minerals to the consumer value and possibilities of industrial use;

- minerals prime cost, which consists of a complex of expenses.

The determination of the specific value of this coefficient can be calculated by formula (5):

$$
K_{e}=\frac{k_{n}+k_{c}+k_{n . t .}+k_{c m}}{z_{i}},
$$

Where:

$k_{n}$ is the coefficient of consumers' availability and the possibility of industrial use of the minerals, varies from 0.7 to 1.0 , it tends to its minimum when the consumers' interest in the minerals decreases, and it increases to 1.0 at high industrial application;

$k_{c}$ is the prime cost coefficient, which takes into account the extraction cost for a separate technology, supposing that the other extraction technology is not used in this field, and is determined from the formula $k_{c}=\left[\left(C_{o 1}-C_{o 2}\right) \cdot K_{c o m}\right] / N_{t}$, in which there is a complication coefficient of conducting works $K_{\text {com }}$, ranging from 0.7 to 0.95 , where $C_{o i}$ is the extraction prime costs of the used technology; $N_{t}$ is the quantity of implemented technologies;

$k_{n t}$ is the possibility coefficient of introducing new equipment, varies from 0.8 to 1.0 , with the increased possibility of introducing a new technology the value of this coefficient tends to 1.0, and vice versa with a decrease it tends to minimum;

$k_{c m}$ is the coefficient taking into account the additional cost of minerals due to transportation from the mine to the processing plant, is ranges from 0.95 to 1.00 depending of the delivery distance and infrastructure development.

The value of productivity criterion can be from 0 to 1.0 , with the operating value ranging from 0.3 to 1.0. This range is divided into three groups described in Table 4. 
Table 4: Value of the economic efficiency coefficient

\begin{tabular}{|l|l|}
\hline $\begin{array}{l}\text { Coefficient } \\
\text { value }\end{array}$ & Description of the coefficient value \\
\hline$K_{e}>0.9$ & $\begin{array}{l}\text { The most favourable economic situation } \\
\text { in the country. Sale of minerals at the highest } \\
\text { price at low prime cost. }\end{array}$ \\
\hline $0.7<K_{e}<0.9$ & $\begin{array}{l}\text { Sale of minerals at average price at low prime } \\
\text { cost. }\end{array}$ \\
\hline $0.3<K_{e}<0.7$ & $\begin{array}{l}\text { Sale of minerals at average price at high prime } \\
\text { cost. }\end{array}$ \\
\hline
\end{tabular}

Given a certain value of each coefficient within a single technology, we will determine the overall efficiency ratio technology with the following formula (6):

$$
K_{g}=0.2 K_{p}+0.5 K_{t}+0.3 K_{e}
$$

The obtained values of the total efficiency coefficient for each technology make the basis for calculating the complex coefficient of compatibility of technologies, and is determined by formula (7):

Where:

$$
K_{g}=x\left(K_{g 1}+K_{g i}\right)
$$

$K_{g 1}$ is the value of the total coefficient of the active technology;

$K_{g i}$ is the value of the total coefficient for the additional extraction technology; $x$ is the relative value that reflects the overlapping of technologies (one to another) and can range from 0 to 1.0, excluding limit values, and is intended to show a decrease in productivity relative to the resulting total coefficient of the technology under research. The value of the coefficient $K_{g}$ can be from 0 to 1.0 , which shows a certain level of compatibility and is detailed in the following Table 5.

From the indicated variants of possible mutual influence of technologies (see Figure 4-6), we determine which cases include the combined technologies under study. Concerning the combined coal production technology, it should be noted that coal extraction is carried out in different parts of the mine field, that is, spaced apart, but using a common part of mining workings for the transportation of materials and minerals to the surface, there is a case of partial overlapping of technologies (see Figure 5). A similar situation is with the combined technology of uranium mining. Thus, both combined technologies fall under the case of partial interference with the normal work of each component of these technologies.

\section{Parameters of feasibility study}

Any feasibility study begins with the analysis of the enterprise, its general characteristics, the level of technical and technological equipment, the placement of products on the market, the overall economic assessment of the enterprise, etc. (Maltsev and Vladyko, 2015b). Such a feasibility study can be made only on the basis of the prepared data set. These indicators presuppose a list of special requirements without which our case of calculation of feasibility is impossible:

- availability of specific investment objectives of the enterprise;

- a clear organization of the production structure for the possibilities of investment attractiveness of the enterprise;

- the possibility of introducing new equipment for active and additional technologies;

- the level of resources depletion, material and labour costs for the improvement of additional technology at the enterprise;

- the level of funds available for investment that need to be raised for research and implementation of additional technology;

- availability of a minimum sufficient level of data about the company to carry out the feasibility study.

With a large number of parameters, the calculation algorithm as a whole is complicated. This is particularly evident in cases where a specific solution has advantages by one indicator, but it is disadvantageous by others. The result is the determination of the significance (priority) of the estimated parameters; and the more parameters, the more difficult it is to determine the true effectiveness of the considered options.

\section{Conclusions}

Two fundamentally different combining technologies are considered for concretization of probable compatibility based on case study. Enterprise system segmentation resulted in the developed algorithm of calculation criteria to find the efficiency of implementation of additional development technology for primary minerals at the same enterprise.

Table 5: Value of the complex technologies compatibility coefficient

\begin{tabular}{|l|l|l|}
\hline Coefficient value & $\begin{array}{l}\text { Characteristics of the } \\
\text { technologies compatibility }\end{array}$ & Description of the technologies compatibility value \\
\hline $1.00>K_{g}>0.81$ & high level of compatibility & $\begin{array}{l}\text { Technologies have zero or minimal influence on one another. } \\
\text { Maximum performance. }\end{array}$ \\
\hline $0.41<K_{g}<0.80$ & intermediate level of compatibility & $\begin{array}{l}\text { The technologies partly complicate each other's operations. } \\
\text { Average performance of both technologies. }\end{array}$ \\
\hline $0.00<K_{g}<0.41$ & low level of compatibility & Technologies significantly complicate each other's functioning. \\
\hline
\end{tabular}

The Mining-Geology-Petroleum Engineering Bulletin and the authors @), 2018, pp. 73-83, DOI: 10.17794/rgn.2018.4.7 
We considered mutual influence of technology by type of interaction, where the first option prevents more than one technology at the same enterprise, the second is a partial overlapping of technologies; and, last, the third type is the independent operation of different technologies at the same enterprise.

The types of input data are defined, where the first type is characterized by graph, table and text data, the second - by processes of mineral extraction, and the third - by economic indicators of the mining enterprise. The coefficients describing the technological and economic processes of the structure of the enterprise are proposed. These include the lithological variety coefficient, which characterizes the physical and chemical characteristics of the minerals and surrounding rocks; the exploration coefficient of the deposit, characterizing the mineral reserves that can be effectively extracted at the enterprise; the coefficient of lithological complexity, characterizing the impact of technology on the extraction process; and the coefficient of economic efficiency, which provides a quantitative and qualitative assessment of the financial risks of the mining. The result of these coefficients is the overall coefficient of compatibility, which shows the expediency of introducing additional technology at the enterprise. And, the final step is a feasibility study, which determines the amount of funds invested in the enterprise development to achieve efficient mining technologies combined at the same enterprise.

\section{References}

Caceres, E. and Alca, J.J. (2016). Potential For Energy Recovery From A Wastewater Treatment Plant. IEEE Latin America Transactions, 14(7), 3316-3321. doi:10.1109/ tla.2016.7587636

Chen, J., Zhao, Y., Song, Q., Zhou, Z. and Yang. S. (2018): Exploration and mining evaluation system and price prediction of uranium resources. Mining of Mineral Deposits, 12(1), 85-94. doi:10.15407/mining 12.01.085

Chernov, A. (1997): Uranium Production Plans and Developments in the Nuclear Fuel Industries of Ukraine. Proceedings of the Annual Symposium - Energy for Sustainable Development: World Nuclear Association, 329-335.

Dychkovskyi, R. O., Lozynskyi, V. H., Saik, P. B., Petlovanyi, M. V., Malanchuk, Y. Z. and Malanchuk, Z. R. (2018): Modeling of the disjunctive geological fault influence on the exploitation wells stability during underground coal gasification. Archives of Civil and Mechanical Engineering, 18(4), 1183-1197. doi:10.1016/j.acme.2018.01.012

Dychkovskyi, R.O. (2015). Forming the bilayer artificially shell of georeactor in underground coal gasification. Naukovyi Visnyk Natsionalnoho Hirnychoho Universytetu, 5, 37-42.

Dychkovskyi, R.O. (2015): Determination of the rock subsidence spacing in the well underground coal gasification. Naukovyi Visnyk Natsionalnoho Hirnychoho Universytetu, 6, 30-36.
English, K. (2002): Combined System Reduction and Sequencing in Complex System Optimization. 9th AIAA/ ISSMO Symposium on Multidisciplinary Analysis and Optimization, 1-12. doi:10.2514/6.2002-5412

Falshtyns'kyy, V., Dychkovs'kyy, R., Lozyns'kyy, V. and Saik, P. (2013): Justification of the gasification channel length in underground gas generator. Annual ScientificTechnical Colletion - Mining of Mineral Deposits 2013, 125-132. doi:10.1201/b16354-23

Falshtynskyy, V., Dychkovskyy, R., Lozynskyy, V. and Saik, P. (2012): New method for justification the technological parameters of coal gasification in the test setting. Geomechanical Processes During Underground Mining, 201-208. doi:10.1201/b13157-35

Falshtynskyy, V.S, Dychkovskyy, R.O, Lozynskyy, V.G, Saik, P.B. and Cabana Cáceres, E. (2017). Formation of thermal fields by the energy-chemical complex of coal gasification. Naukovyi Visnyk Natsionalnoho Hirnychoho Universytetu, 5, 36-42.

Fatkhutdinov, V.H., \& Bazaluk, O. (2018). The Importance of the Brain Neuro-Programming Technologies in National and Regional Security Strategies. Philosophy and Cosmology, (20), 74-82. doi:10.29202/phil-cosm/20/6

Gorova, A., Pavlychenko, A., Kulyna, S. and Shkremetko, O. (2012). Ecological problems of post-industrial mining areas. Geomechanical Processes During Underground Mining, 35-40. doi:10.1201/b13157-7

Khadse, A. N., Qayyumi, M., Mahajani, S. M. and Aghalayam, P. (2006): Reactor Model for the Underground Coal Gasification (UCG) Channel. International Journal of Chemical Reactor Engineering, 4(1). doi:10.2202/15426580.1351

Khomenko, O., Kononenko, M. and Myronova, I. (2017). Ecological and technological aspects of iron-ore underground mining. Mining of Mineral Deposits, 11(2), 59-67. doi:10.15407/mining 10.02.059

Kuz'menko, O., Petlyovanyy, M. and Stupnik, M. (2013). The influence of fine particles of binding materials on the strength properties of hardening backfill. Annual Scientific-Technical Colletion - Mining of Mineral Deposits 2013, 45-48. doi:10.1201/b16354-10

Lavrov, N.V. (1957): Physical and chemical bases of combustion and gasification of fuel. Metallizdat, Moscow, $40 \mathrm{p}$.

Lozynskyi, V.G., Dychkovskyi, R.O., Falshtynskyi, V.S., Saik, P.B., Malanchuk, Ye.Z. (2016): Experimental study of the influence of crossing the disjunctive geological fault on thermal regime of underground gasifier. Naukovyi Visnyk Natsionalnoho Hirnychoho Universytetu, 5, 21-29.

Lozynskyi, V.H., Dychkovskyi, R.O., Falshtynskyi, V.S. and Saik, P.B. (2015): Revisiting possibility to cross the disjunctive geological faults by underground gasifier. Naukovyi Visnyk Natsionalnoho Hirnychoho Universytetu, 4, 22-27.

Mahrous A.M. Ali. (2018): Software application in mining engineering. Mining of Mineral Deposits, 12(1), 48-53. doi: 10.15407/mining 12.01.048

Maltsev, D. and Vladyko, O. (2015a): A new approach for uranium mining Novokostiantynivka. IGTM NAS, 120, $202-212$.

The Mining-Geology-Petroleum Engineering Bulletin and the authors $\odot$, 2018, pp. 73-83, DOI: 10.17794/rgn.2018.4.7 
Maltsev, D. and Vladyko, O. (2015b): The economic efficiency analysis of uranium oxide extraction using geotechnological method in underground conditions of Vatutinsky deposit for the poor and extremely poor ores. IGTM NAS, 123, 116-125.

Petlovanyi, M.V., Lozynskyi, V.H., Saik, P.B. and Sai, K.S. (2018): Modern experience of low-coal seams underground mining in Ukraine. International Journal of Mining Science and Technology. (Article in Press). doi:10.1016/j. ijmst.2018.05.014

Pivnyak, G,G, Dychkovskyi R.O, Falshtynskyi, V.S. and Cabana, Cáceres Edgar. (2017) Energy Efficiency and Economic Aspects of Mining Wastes Utilization within the Closed Cycle of Underground Gas Generator. Advanced Engineering Forum, 25, 1-10. doi:10.4028/www.scientific.net/AEF.25.1

Pivnyak, G., Dychkovskyi, R., Smirnov, A. and Cherednichenko, Y. (2013). Some aspects on the software simulation implementation in thin coal seams mining. Energy Efficiency Improvement of Geotechnical Systems, 1-10. doi:10.1201/b16355-2

Saik, P.B., Dychkovskyi, R.O., Lozynskyi, V.H., Malanchuk, Z.R. and Malanchuk, Ye.Z. (2016): Revisiting the underground gasification of coal reserves from contiguous seams. Naukovyi Visnyk Natsionalnoho Hirnychoho Universytetu, 6, 60-66.

Shemyakin, E.I. (2007): Physical and mechanical fundamentals of unconventional technologies of solid mineral development. Physical Mesomechanics, 10(1-2), 87-93. doi: 10.1016/j.physme.2007.06.009

Singh, S.K. and Jayanthu, S. (2011): Implication of continuous miner in room and pillar mining for mass exploitation of underground coal deposits: An overview. Journal of Mines, Metals and Fuels, 59(3-4), 83-95.
Smol, M., Kulczycka, J. and Avdiushchenko, A. (2017): Circular economy indicators in relation to eco-innovation in European regions. Clean Technologies and Environmental Policy, 19(3), 669-678. doi:10.1007/s10098-016-1323-8

Snihur, V., Malashkevych, D. and Vvedenska, T. (2016): Tendencies of coal industry development in Ukraine. Mining of Mineral Deposits, 10(2), 1-8. doi:10.15407/mining 10.02.001

Tabachenko, M., Vladyko, O., Khomenko, E. and Maltsev, D. (2012): Fizyko-khimichna heotekhnolohiia. National Mining University, Dnipro, 310 p.

Tjiparuro, Z., Kgengwenyane, O. and Oageng, M. (2018): Research, science, technology, and innovation parks: reviewing both mining and research tendencies. Mining of Mineral Deposits, 12(2), 58-62. doi:10.15407/mining12.02.058

Vladyko, O. (2013): Technological parameters of cutoff curtains, created with the help of inkjet technology. Annual Scientific-Technical Colletion - Mining of Mineral Deposits 2013, 299-302. doi:10.1201/b16354-55

Vladyko, O. and Maltsev, D. (2015): The new method of extraction of poor and extremely poor ores in underground conditions of Vatutynske deposit (Ukraine). New Developments in Mining Engineering 2015, 247-251. doi:10.1201/ b19901-44

Xin, L., Wang, Z., Wang, G., Nie, W., Zhou, G., Cheng, W. and Xie, J. (2017): Technological aspects for underground coal gasification in steeply inclined thin coal seams at Zhongliangshan coal mine in China. Fuel, 191, 486-494. doi: 10.1016/j.fuel.2016.11.102.

Zhao, Jing. (2010): Research on improving ecological compensation mechanism of mineral resources development. International Conference on E-Health Networking Digital Ecosystems and Technologies (EDT), 2, 567-571.doi: 10.1109/edt.2010.5496460 